\title{
Global diversity of inland water cnidarians
}

\author{
Thomas Jankowski · Allen G. Collins • \\ Richard Campbell
}

(C) Springer Science+Business Media B.V. 2007

\begin{abstract}
Global diversity of inland water cnidarians is low, containing $<40$ species belonging to phylogenetically distinct groups representing independent invasion events: the common and cosmopolitan hydras (12 15 species); the sporadically occurring freshwater medusae (6 $16 \mathrm{sp}$.); the Cordylophorinae (2 sp.); the parasitic Polypodium (1 sp.); the medusae occurring in saline lakes (4 sp.). Freshwater cnidarians inhabit nearly all types of freshwater on all continents (except Antarctica), but only a few species have cosmopolitan distributions. Due to uncertainty in species knowledge, fine scale regions of endemicity are not yet clear.
\end{abstract}

Guest editors: E. V. Balian, C. Lévêque, H. Segers \& K. Martens

Freshwater Animal Diversity Assessment

T. Jankowski $(\square)$

Water Resources Department, Swiss Federal Institute of Aquatic Science and Technology (Eawag), Dubendorf 8600, Switzerland

e mail: thomas.jankowski@eawag.ch

\section{A. G. Collins}

NMFS, National Systematics Laboratory, National Museum of Natural History, MRC 153, Smithsonian Institution, P.O. Box 37012, Washington, DC 20013 7012, USA

R. Campbell

Department of Developmental and Cell Biology, University of California, Irvine, CA 92697, USA
Keywords Hydra Polypodium .

Cordylophora $\cdot$ Craspedacusta $\cdot$ Distribution · Species diversity $\cdot$ Freshwater cnidarian

\section{Introduction}

The Cnidaria is composed of medusae, anemones, corals, and other polyps. Although the phylum is remarkably successful in the marine realm (7000+ species), there are few cnidarian representatives in inland waters. The freshwater species fall into four phylogenetically disparate groups, all save perhaps one belonging to Hydrozoa (Bouillon \& Boero, 2000a, b; Collins, 2002): (1): the common Hydra, a group of secondarily simple, solitary polyps (Fig. 1A) without medusae; (2) Cordylophorinae, an anthoathecate group that contains freshwater colonial hydroids (Cordylophora and Pachycordyle) (Fig. 1 C); (3) freshwater medusae, e.g., Craspedacusta and Limnocnida, which have simple polyp stages that lack tentacles (Fig. 1B); and (4) Polypodium, an unusual parasite of fish eggs recently assigned to its own class, Polypodiozoa (Bouillon \& Boero, 2000a). Medusae species from saline lakes belong to two distinct groups within Anthoathecata.

Cnidarians are found in nearly all types of freshwater, i.e., streams, rivers, ponds, and lakes, but they mainly occur in mesotrophic to eutrophic habitats. When they are abundant, they can be major predators on small invertebrates (Dumont, 1994; 
Fig. 1 Habitus of freshwater cnidarians. (A) Hydra (3 $10 \mathrm{~mm})$. (B) Medusa (3 $20 \mathrm{~mm}$ ) and Polyp stage (3 polyp colony, $0.5 \mathrm{~mm}$ ) of Craspedacusta sowerbii. (C) Part of colony of Cordylophora $(5 \mathrm{~mm})$. (A and $\mathbf{C}$ from Holstein, 1995 and $\mathbf{B}$ from Slobodkin \& Bossert, 2001)

Jankowski et al., 2005) and occasionally tiny fish, which they catch and immobilize with their characteristic stinging cells, cnidocytes. They are basically planktivorous (Dumont, 1994), though polyps are also benthivorous.

Freshwater cnidarians are of minor economic or medical interest. Cordylophora occasional grow such massive colonies that they foul boats and clog waterways, hydras are considered pests in fish hatcheries, and Polypodium is a threat to the caviar industry.

\section{Species diversity}

Worldwide diversity of inland water cnidarians is low, probably less than 40 species (in $<15$ genera, Tables 1, 2).

Freshwater medusae More than 20 species (in 6 genera) have been recorded. However, about half of

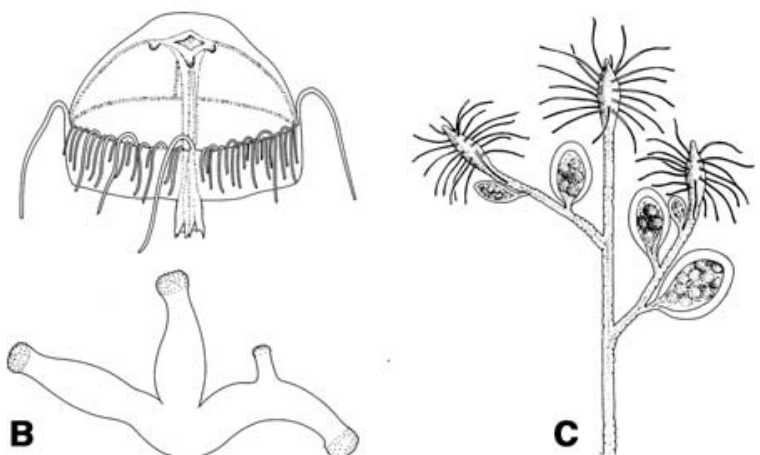

them may not be valid, because the specific value of many characters is presently uncertain (Bouillon \& Boero, 2000b; Jankowski, 2001). Within Craspedacusta, Astrohydra, and Limnocnida, only three to five, one, and six species, respectively, are certain. It is even possible that Limnocnida contains just two species, one each in India and Africa (Bouillon \& Boero, 2000b). The Indian genera Mansariella and Keralika are uncertain (Bouillon \& Boero, 2000b), as is the holarctic Calpasoma (Holstein, 1995). In sum, the number of accepted freshwater medusae species ranges from 6 to 16, though the true diversity may be higher.

Hydras Of the 80 described species, probably fewer than 15 are distinct. Species are clustered into four groups (Campbell, 1987) that reflect and extend Schulze's (1917) genera, Hydra, Pelmatohydra, and Chlorohydra, which are no longer recognized. These groups are: viridissima group (green, due to intracellular symbiotic algae), probably consisting of a single

Table 1 Species diversity by Family of inland water cnidarian in different biogeographic regions

\begin{tabular}{|c|c|c|c|c|c|c|c|c|c|}
\hline Biogeographic region & PA & NA & NT & AT & OL & $\mathrm{AU}$ & PAC & ANT & World \\
\hline Olindiidae $^{\mathrm{a}}$ & 48 & $1^{\mathrm{c}}$ & 1 & 24 & 26 & 1 & 1 & 0 & 616 \\
\hline Australomedusidae $^{\mathrm{b}}$ & 0 & 0 & 0 & 0 & 0 & 2 & 0 & 0 & 2 \\
\hline Moerisiidae $^{\mathrm{b}}$ & 1 & 0 & 0 & 1 & 0 & 0 & 0 & 0 & 2 \\
\hline Hydridae $^{\mathrm{a}}$ & 46 & 67 & 23 & 23 & 45 & 24 & 0 & 0 & 0 \\
\hline Polypodiidae $^{\mathrm{a}}$ & 1 & 1 & 0 & 0 & 0 & 0 & & 0 & 1 \\
\hline Cordylophoridae $^{\mathrm{a}}$ & 2 & 1 & 1 & 1 & 1 & 1 & & 0 & 2 \\
\hline Total & 1218 & 910 & 45 & 69 & 712 & 68 & 2 & 0 & 1323 \\
\hline
\end{tabular}

PA: Palaearctic, NA: Nearctic, NT: Neotropical, AT: Afrotropical, OL: Oriental, AU: Australasian, PAC: Pacific Oceanc Islands, ANT: Antarctic

\footnotetext{
a Freshwater species

b Salt lake species

c Halmomises lacustris found only once in a lagoon in Trinidad was not considered due to the uncertain status (see Jankowski 2001 for discussion)
} 
Table 2 Genera diversity by Family of inland water cnidarian in different biogeographic regions

\begin{tabular}{llllllllll}
\hline Biogeographic region & PA & NA & NT & AT & OL & AU & PAC & ANT & World \\
\hline Olindiidae $^{\mathrm{a}}$ & 2 & $1^{\mathrm{c}}$ & 1 & 2 & 24 & 1 & 1 & 0 & 24 \\
Australomedusidae $^{\mathrm{b}}$ & 0 & 0 & 0 & 0 & 0 & 1 & 0 & 0 & 1 \\
Moerisiidae $^{\mathrm{b}}$ & 1 & 0 & 0 & 1 & 0 & 0 & 0 & 0 & 1 \\
Hydridae $^{\mathrm{a}}$ & 1 & 1 & 1 & 1 & 1 & 1 & 0 & 0 & 0 \\
Polypodiidae $^{\mathrm{a}}$ & 1 & 1 & 0 & 0 & 0 & 0 & & 0 & 1 \\
Cordylophoridae $^{\mathrm{a}}$ & 2 & 1 & 1 & 1 & 1 & 1 & & 0 & 2 \\
Total & 7 & 4 & 3 & 5 & 46 & 4 & 1 & 0
\end{tabular}

PA: Palaearctic, NA: Nearctic, NT: Neotropical, AT: Afrotropical, OL: Oriental, AU: Australasian, PAC: Pacific Oceanc Islands, ANT: Antarctic

${ }^{\text {a }}$ Freshwater species

b Salt lake species

c Halmomises lacustris found only once in a lagoon in Trinidad was not considered due to the uncertain status (see Jankowski 2001 for discussion)

species; oligactis group (large stalked hydras), consisting of 35 species; braueri group (small hermaphroditic hydras), consisting of 35 species, and the remaining vulgaris group (sometimes called common hydra), consisting of 46 species.

Polypodium hydriforme is the only described species of Polypodium.

Cordylophorinae Cordylophora and Pachycordyle are usually considered to each contain a single species in freshwater.
Saline lake medusae Australomedusa and Moerisia each have two species described from saline lakes.

\section{Phylogeny and historical processes}

Not surprisingly, given their small sizes and soft bodies, there is no fossil record for freshwater cnidarians. Nevertheless, their morphologies and
Fig. 2 Hypothesis of cnidarian relationships highlighting independent origins of at least four freshwater groups (bold, all caps), based on Collins (2002), Collins et al. (2005), and Collins et al. (2006)

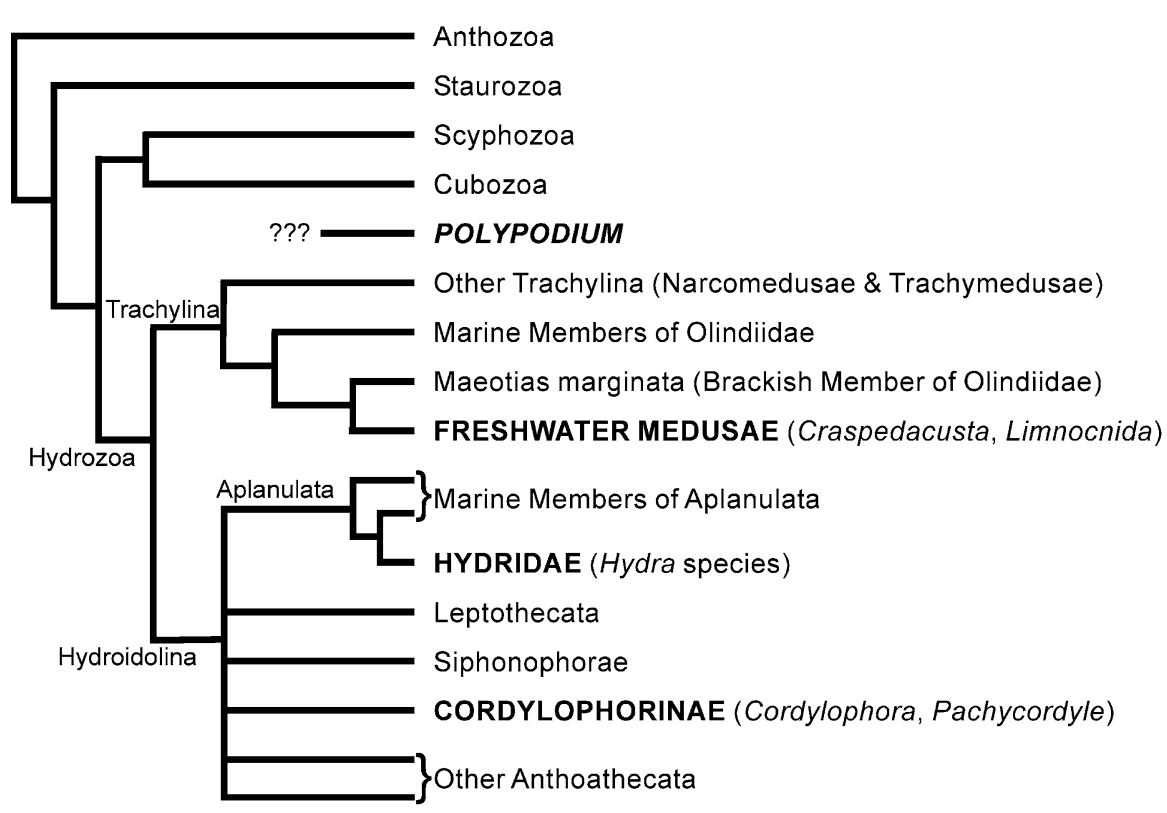


Fig. 3 Distribution of freshwater cnidarians. (A) Distribution of the freshwater medusae genera Craspedacusta (light gray) and Limnocnida (dark gray) (extended after Dumont, 1994). C. sowerbii is the only cosmopolitan species. East Asia (China and Japan) is the only area with more than one Craspedaucsta species (2 5 species). Limnocnida is distributed in Africa (1 3 species) and India (1 3). From India two other species with uncertain status were described. (B) Diversity of Hydra. There are no distribution data for large dry areas of Africa, Australia and Asia. These areas have been filled in according to the surrounding areas. Hydra are present on continental islands (Japan, Madagascar, New Zealand, New Caledonia, Greenland, Sri Lanka, and British Isles including Orkney and Shetland Islands). They are absent from most oceanic islands. Hydra have been reported from Faroe Islands, Iceland and La Reunion but not from Antarctica
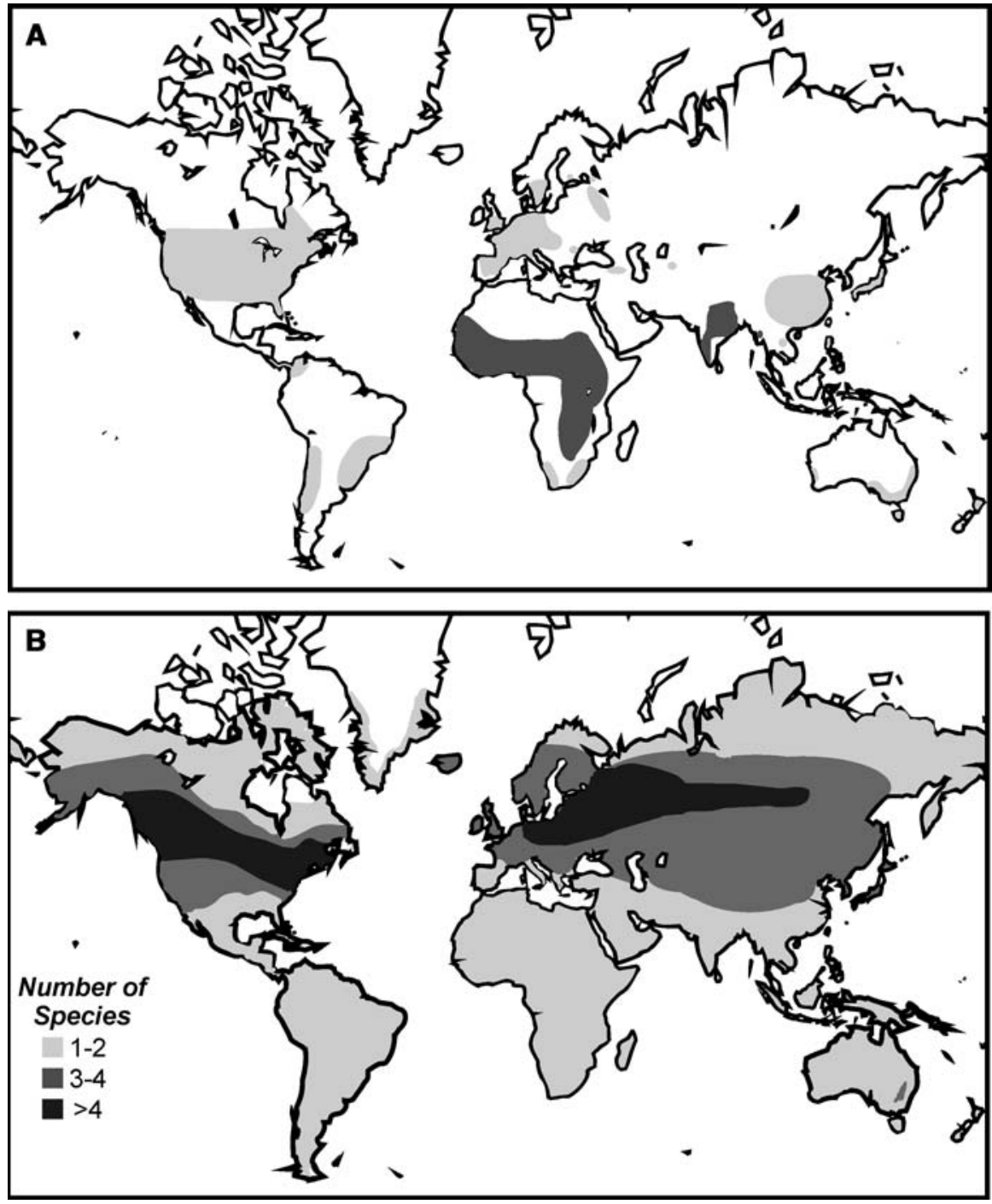

distributions have been used to infer some evolutionary histories. Analysis of molecular sequence data is now putting some of these relationships on a firm basis (Fig. 2). Freshwater medusae originated within Trachylina and form the sister group to the brackish species Maeotias marginata (Collins, 2002; Collins et al., 2006). Hydra (Hydridae) falls within a clade (Aplanulata) of anthoathecate hydrozoans that develop from egg to polyp via a nonciliated stereogastrula stage, i.e., lacking the characteristic ciliated planula (Collins et al., 2005, 2006). These data show that Moerisia is not part of Aplanulata, but they have not provided resolution among the many lineages comprising Anthoathecata. Molecular data have yet to be published for Cordylophora, Pachycordyle, or
Australomedusa, but they are classified in the anthoathecate group Filifera. There may have been multiple invasions of freshwater within Cordylophorinae, as most species within the group are adapted to brackish conditions (Stepanjants et al. 2000). Molecular data from the $18 \mathrm{~S}$ ribosomal gene have been gathered for Polypodium, but this gene has undergone such a high rate of divergence in Polypodium, that it appears to be an unreliable indicator of its phylogenetic position (Kim et al., 1999). Unfortunately, no molecular clock estimates have been published for the divergences of lineages of freshwater cnidarians.

Although the freshwater cnidarian groups have independent phylogenetic origins, three out of the four have some tie to the Ponto-Caspian basin 
Fig. 4 Distribution of cnidarian species and genera in each zoogeographical region (species number/genus number). PA Palaearctic, NA Nearctic, NT Neotropical, AT Afrotropical, OL Oriental, AU Australasian, PAC Pacific Oceanc Islands, ANT Antarctic

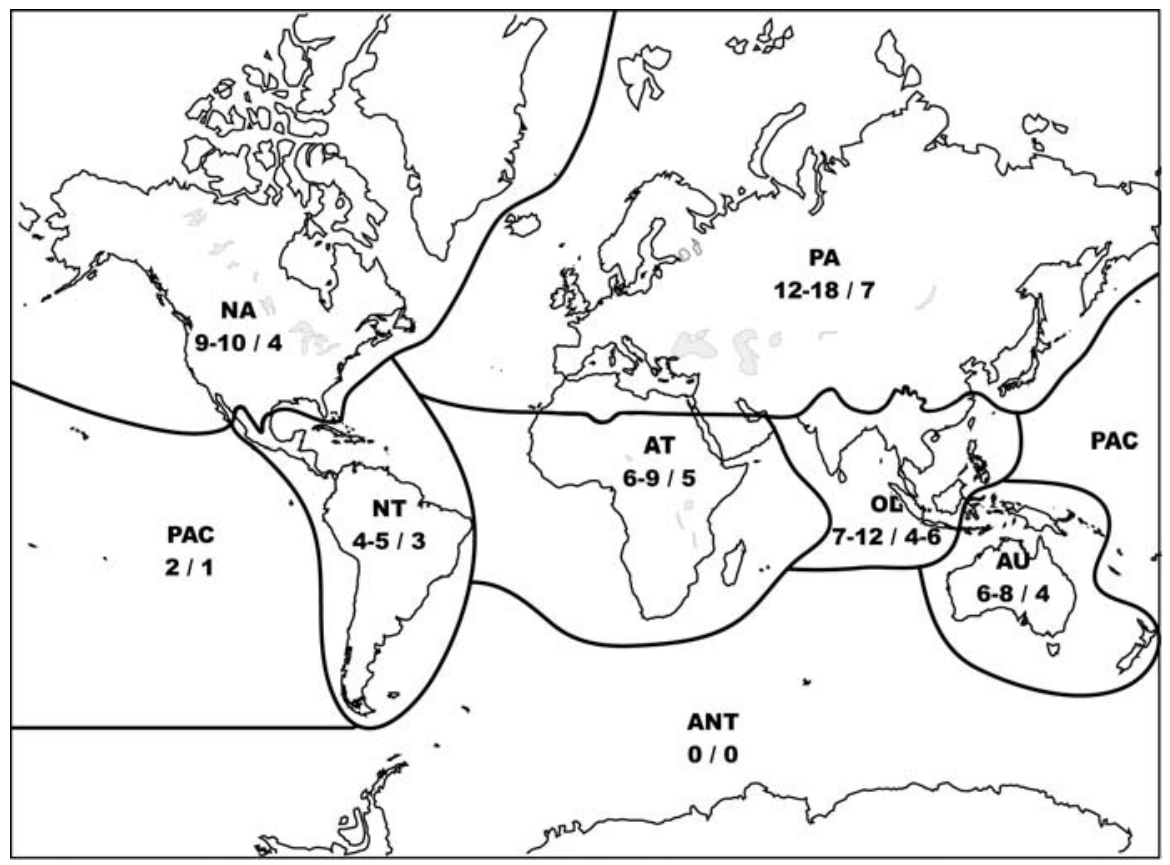

encompassing the Black, Azov, Caspian and Aral Sea regions. By providing relatively stable brackish water conditions over many millions of years, this basin may have been critical for the origin of freshwater groups (Croghan, 1983). Three observations fit with such a scenario for three of the freshwater cnidarian groups: (1) the living sister group to the freshwater medusae is a brackish species (Maeotias marginata) from the Black Sea (Collins et al., 2006); (2) Cordylophora caspia was originally identified from the Caspian Sea; and (3) the Volga River empties into the Caspian Sea and it is in this region that Polypodium is most prevalent (Raikova, 2002).

\section{Present distribution and main areas of endemicity}

Tables 1 and 2 summarize the species and genera diversity of inland water cnidaria in particular biogeographic regions. Freshwater cnidarians are distributed worldwide (Figs. 3, 4).

Freshwater medusae Craspedacusta sowerbii is the most widespread freshwater medusa (Fig. 3A), and has successfully colonized all continents, except Antarctica, during the 20th century (Dumont, 1994). This still ongoing expansion is probably related to intercontinental human mediated co-transportation of drought-resistant resting stages with plants and fish (Dumont, 1994) and climate changes. The probable origin and most diverse region of Craspedacusta is the Yangtze River basin, in which up to 4 species are endemic (Jankowski, 2001). Whereas Craspedacusta seems to have mainly a subtropical to temperate distribution, Limnocnida is tropical from West-Africa to India and Myanmar.

Hydras Hydra are probably unable to disperse across oceans (they are absent from oceanic islands) and this is reflected in their geographical distributions. The viridissima and vulgaris hydras are essentially cosmopolitan, and were probably present before the continents separated. But boreal and austral vulgaris hydra have diverged slightly from each other. The oligactis and braueri hydra are restricted to the northern continents and presumably arose after the separation of northern and southern land masses. In these two groups there has been some divergence between species of $\mathrm{N}$. America and Eurasia. Species diversity is lower at low and very high latitudes and higher in mountainous regions (Fig. 3B). Most species are broadly distributed within one or several continents.

Polypodium Polypodium is known from water basins of Russia, Romania, Iran, and North America (Raikova, 2002). 
Cordylophorinae Cordylophora is normally found in brackish water, but its unusual tolerance of salinity allows it to span ecosystems from oceans to fresh water. It has been recorded sporadically but widely in freshwater on all continents except Antarctica (Folino, 2000). Pachycordyle kubotai is known only from Lake Biwa in Japan (Stepanjants et al., 2000).

Salt lake medusae Australomedusa (2 sp.) is only known from Australia. Moerisia (2 sp.) is known from Lake Qurun (Egypt) and the Caspian Sea (Jankowski, 2001).

Acknowledgements This work was partly funded by the Swiss Federal Office of Education and Science within the framework of the European Union Environment and Climate projects CLIME (EVK1 CT 2002 00121) and Eurolimpacs (GOCE CT 2003 505540).

\section{References}

Bouillon, J. \& F. Boero, 2000a. The hydrozoa: a new classi fication in the light of old knowledge. Thalassia Salentina 24: 345 .

Bouillon, J. \& F. Boero, 2000b. Synopsis of the families and genera of the Hydromedusae of the world, with a list of the worldwide species. Thalassia Salentina 24: 47296.

Campbell, R. D., 1987. A new species of Hydra (Cnidaria: Hydrozoa) from North America with comments on spe cies clusters within the genus. Zoological Journal of the Linnean Society 91: 253263.

Collins, A. G., 2002. Phylogeny of Medusozoa and the evo lution of cnidarian life cycles. Journal of Evolutionary Biology 18: 418432.

Collins, A. G., P. Schuchert, A. C. Marques, T. Jankowski, M. Medina \& B. Schierwater, 2006. Medusozoan phylogeny and character evolution clarified by new large and small subunit rDNA data and an assessment of the utility of phylogenetic mixture models. Systematic Biology 55: 97 115 .
Collins, A. G., S. Winkelman, H. Hadrys \& B. Schierwater, 2005. Phylogeny of Capitata and Corynidae (Cnidaria, Hydrozoa) in light of mitochondrial 16S rDNA data. Zoological Scripta 34: 9199.

Croghan, P. C., 1983. Osmotic regulation and the evolution of brackish and fresh water faunas. Journal of the Geolog ical Society London 140: 3946.

Dumont, H. J., 1994. The distribution and ecology of the fresh and brackish water medusae of the world. Hydrobiologia 272: 112 .

Folino, N. C., 2000. The freshwater expansion and classifica tion of the colonial hydroid Cordylophora (Phylum Cnidaria, Class Hydrozoa). In Pederson, J. (ed.), Marine Bioinvasions: Proceedings of the First National Confer ence, January 24 27, 1999. Massachusetts Institute of Technology Sea Grant College Program, Cambridge, MA: 139144.

Holstein, T., 1995. Cnidaria: Hydrozoa. In Schwoerbel, J. \& P. Zwick (eds), Süßwasserfauna von Mitteleuropa, Vol. 12. Gustav Fischer, Stuttgart: 67101.

Jankowski, T., 2001. The freshwater medusae of the world a taxonomic and systematic literature study with some remarks on other inland water jellyfish. Hydrobiologia 462: 91113.

Jankowski, T., T. Strauss \& H. T. Ratte, 2005. Trophic inter actions of the freshwater jellyfish Craspedacusta sowerbii. Journal of Plankton Research 27: 811823.

Kim, J. H., W. Kim \& C. W. Cunningham, 1999. A new perspective on lower metazoan relationships from $18 \mathrm{~S}$ rDNA sequences. Molecular Biology and Evolution 16: 423427.

Raikova, E. V., 2002. Polypodium hydriforme infection in the eggs of acipenseriform fishes. Journal of Applied Ich thyology 18: 405415.

Schulze, P., 1917. Neue Beiträge zu einer Monographie der Gattung Hydra. Archiv für Biontologie 4: 29119.

Slobodkin, L. B. \& P. E. Bossert, 2001. Cnidaria. In Thorp, J. E. \& A. P. Covich (eds), Ecology and Classification of North American Freshwater Invertebrates. Academic Press: 135154.

Stepanjants, S. D., O. A. Timoshkin, B. A. Anokhin \& T. A. Napara, 2000. A new species of Pachycordyle (Hydrozoa, Clavidae) from Lake Biwa (Japan), with remarks on this and related Clavid genera. Scientia Marina 64(Suppl. 1): 225236. 